\title{
PEMEROLEHAN MORFOLOGI DAN SINTAKSIS PADA ANAK USIA 2-4 TAHUN (KAJIAN PSIKOLINGUISTIK)
}

\author{
Fadlia Rafiyanti ${ }^{1)}$ \\ ${ }^{1}$ Pendidikan Bahasa dan Sastra Indonesia, Fakultas Ilmu Tarbiyah dan Pendidikan, Universitas Islam Negeri Syarif \\ Hidayatullah Jakarta, Jl. Ir. H. Djuanda No.95, Ciputat, Tangerang Selatan, Banten 15412, Indonesia. \\ E-mail: fadliarafayantiii@gmail.com
}

\begin{abstract}
Abstrak
Penelitian ini bertujuan untuk mengetahui dan mendeskripsikan sistem pemerolehan bahasa anak yang berusia 2 tahun 6 bulan dan anak yang berusia 3 tahun 1 bulan, khususnya yang mencakup pada tataran Morfologi dan Sintaksis. Metode yang digunakan dalam penelitian ini adalah metode kualitatif deskriptif. Subjek penelitian adalah Sheva yaitu anak yang berumur 2 tahun 6 bulan dan Raya anak yang berumur 3 tahun 1 bulan. Dapat disimpulkan bahwa: 1) Pada tataran Morfologi, anak yang berusia 2 tahun 6 bulan (Sheva) kata yang diproduksinya bertambah bersifat monomorfemik, belum nampak morfem yang membedakan arti kata, mampu mengatakan lebih dari suku kata, meskipun belum teratur sudah mampu menyusun kalimat sederhana, adanya proses afiksasi. Sedangkan pada anak berusia 3 tahun 1 bulan (Raya), kata yang diproduksinya semakin banyak, kata monomorfemik sudah lebih jelas, nampak morfem yang dapat membedakan arti kata, terdapat morfem bebas dan morfem terikat, penyusunan kalimat sudah teratur dan lebih panjang, dapat menggunakan tiga atau lebih kata, terdapat proses afiksasi. 2) Pada tataran Sintaksis, anak yang berusia 2 tahun 6 bulan (Sheva), pola kalimat yang dihasilkan sangat sederhana, kalimat yang masih tidak lengkap, pengucapan fonem yang belum sempurna, sudah mampu menghasilkan kalimat deklaratif, imperatif dan interogatif secara sederhana. Sedangkan anak yang berusia 3 tahun 1 bulan (Raya), sudah dapat menghasilkan kalimat yang menyerupai orang dewasa, pelafalannya sudah cukup jelas, sudah mampu multikata dan dapat menghasilkan kalimat deklaratif, imperatif, dan interogatif yang jelas.
\end{abstract}

Kata Kunci: Pemerolehan Bahasa Anak; Morfologi; Sintaksis.

\begin{abstract}
This study aims to determine and describe the language acquisition system of children aged 2 years 6 months and children aged 3 years 1 month, especially those at the level of morphology and syntax. The method used in this research is descriptive qualitative method. The research subjects were Sheva, a child aged 2 years 6 months and Raya, a child aged 3 years and 1 month. It can be concluded that: 1) At the level of morphology, a child who is 2 years and 6 months old (Sheva) produces more words that are monomorphemic, there is no morpheme that distinguishes the meaning of words, is able to say more than syllables, although not regularly able to compose simple sentences, there is an affixation process. Whereas in children aged 3 years and 1 month (Raya), they produce more words, monomorphemic words are clearer, there are morphemes that can distinguish the meaning of words, there are free morphemes and bound morphemes, sentence arrangement is regular and longer, can use three or more words, there is an affixation process. 2) At the level of syntax, children aged 2 years 6 months (Sheva), the resulting sentence patterns are very simple, sentences that are still incomplete, imperfect pronunciation of phonemes, are able to produce simple declarative, imperative and interrogative sentences. Meanwhile, children who are 3 years and 1 month old (Raya) can produce sentences that resemble adults, their pronunciation is clear enough, they are able to multi-word and can produce clear declarative, imperative, and interrogative sentences.
\end{abstract}

Keywords: Acquisition of Children's Language; Morphology; Syntax.

\section{Pendahuluan}

Semua manusia pasti bisa berbahasa dan memiliki bahasa, bahasa adalah hal yang mendasar yang ada di dalam diri manusia, sama seperti bernafas yang mana sangat dibutuhkan bagi semua orang. Manusia memiliki kemampuan untuk mengembangkan akal budi dan pikirannya. Bahasa merupakan suatu alat komunikasi baik lisan maupun tulisan yang diperoleh manusia sejak lahir sampai usia lima tahun yang mana disebut dengan pemerolehan bahasa. Pada awal bayi dilahirkan, pasti belum memiliki kemampuan berbicara dengan orang 
lain. Sejak awal orang tua mengajak bayi berbicara seolah-olah sudah dapat berbicara, hal tersebut merupakan bagian dari interaksi di lingkungannya. Penguasaan bahasa oleh seorang anak dimulai dari pemerolehan bahasa pertama yang seringkali disebut bahasa ibu. Chaer berpendapat bahwa pemerolehan bahasa merupakan suatu proses yang berlangsung pada otak seorang anak ketika ia memperoleh bahasa pertamanya. Dengan kata lain bahasa merupakan sarana bagi seorang anak untuk mengungkapkan suatu pikiran, perasaan, kemauan, dan sebagainya dalam berkomunikasi.

Hal yang sulit dibuktikan dan mengagumkan ialah bagaimana seseorang dapat memperoleh bahasa. Bahkan, orang dewasa terkesima dengan perkembangan bahasa yang terjadi pada anak. Pemerolehan bahasa yaitu suatu proses yang cukup lama yang mana dimulai sejak anak belum sama sekali mengenal bahasa dan saat anak berusia 3-4 tahun seorang anak secara khusus dapat memperoleh banyak kosa kata sampai anak tersebut fasih berbahasa yang mana seorang anak akan memperoleh bahasa secara terus menerus seiring bertambahnya usia seorang anak. Gleason dan Reatner menjelaskan bahwa Linguistik dan Psikolinguistik modern menjelaskan tentang langkah-langkah yang dipelajari, bagaimana dan apa yang dipelajari oleh seorang anak melalui kompetensi komunikasi (Reatner, 1998). Saat anak berusia 0-6 tahun, dalam sebuah proses tataran kalimat umumnya sedang berlangsungnya beberapa proses seperti pada tingkatan fonologi, morfologi, sintaksis, dan semantik. Anak akan mengucapkan kata tanpa tahu kata tersebut berarti apa dan bermaksud pada makna apa. Setelah beberapa kata diperoleh, baru anak berbicara dengan kalimat lengkap dan diikuti dengan nada yang berbeda-beda.

Meskipun begitu, banyak sekali pertanyaan yang tidak dapat terjawab mengenai bagaimana sebenarnya seorang anak dapat memperoleh bahasa, bagaimana anak dapat mampu menghasilkan ujaran yang belum pernah dihasilkan sebelumnya? Bagaimana seorang anak dapat menentukan sebuah makna kata? Para peneliti belum setuju tentang bagaimana seorang anak dapat memperoleh sebuah bahasa. Apakah seorang anak belajar bahasa karena orang dewasa mengajarkannya? Apakah ada program genetik dalam pemerolehan bahasa? Atau apakah mereka belajar bahasa, karena bahasa adalah sebuah alat untuk berkomunikasi? Ilmu psikolingustiklah yang mengkaji atau membahas tentang pemerolehan bahasa tersebut. Telah banyak teori yang dikemukakan oleh para ahli tentang bidang disiplin berbeda bagaimana proses pemerolehan bahasa terjadi pada anak. Tanpa disadari, penguasaan bahasa dapat diperoleh atau dikuasai anak meski tidak ada pengajaran formal pada umumnya.

Chomsky memberikan pendapat yang dikutip dalam Subyakto-Nababan, bahwa setiap orang memiliki Faculties of the Mind, sejenis bagian dari intelektual yang ada di dalam otak yang mana salah satu bagiannya yaitu untuk pemerolehan bahasa. Biasanya anak yan normal dapat memperoleh bahasa ibu dengan singkat, hal tersebut bukan karena ada rangsangan saja melainkan si anak melakukan repon terhadap suatu pembicaraan.

Tetapi, pada dasarnya sejak lahir seorang anak sudah mendapat seperangkat peralatan untuk memperoleh bahasa ibu yang dinamakan Language Acquisition Device (LAD) atau lebih dikenal dengan nama piranti pemerolehan bahasa (Nababan, 1992).

Dengan demikian, dari beberapa pemaparan dan pertanyaan di atas, penelitian ini diarahkan pada pemerolahan bahasa melalui ujaran percakapan dengan keluarga yang digunakan anak usia 2-4 tahun dalam bertutur dilingkungannya menggunakan tataran morfologi dan sintaksis. Penelitian ini bertujuan untuk 1) Menjelaskan pemerolehan bahasa pada anak usia 2-4 tahun dalam tataran morfologi; dan 2) Menjelaskan pemerolehan 
bahasa pada anak usia 2-4 tahun dalam tataran sintaksis.

Istilah pemerolehan sering kali dipakai untuk persamaan istilah dalam bahasa Inggris (Acquisition) yang diartikan sebagai proses penguasaan bahasa secara natural saat seorang anak mempelajari bahasa ibunya (Narative Language) (Darjowisdjojo, 2010).

Krashen dalam (Schutz, 2006) berpendapat bahwa pemerolehan bahasa sebagai "The product of a subconscious process very similar to the process children undergo when they acquire their first language”. Dari penjelasan tersebut Krashen menjelaskan bahwa pemerolehan bahasa yaitu suatu proses bagaimana seorang anak dapat berbahasa atau memperoleh bahasa ibunya. Maka dari itu biasanya proses berbahasa itu berada di ambang sadar yang mana kita tidak sadar dalam memperoleh bahasa tetapi dalam berkomunikasi ia tahu bahwa sedang menggunakan bahasa. Schutz berpendapat lagi bahwa hasil dari pemerolehan bahasa yaitu kemampuan yang bersifat di ambang sadar dan si pemeroleh tidak sadar dengan kaidah bahasa yang didapatkannya.

(Sigel, 2020) menyatakan bahwa pemerolehan bahasa ialah suatu proses menyesuaikan rangkaian hipotesis yang seorang anak dengan ucapan orang tua hingga ia dapat menggunakan kaidah tata bahasa yang menurutnya benar atau baik dan sederhana sesuai dengan bahasa yang berkaitan. Pemerolehan bahasa dibagi menjadi dua, merpakan pemerolehan bahasa pertama dan pemerolehan bahasa kedua. Pemerolehan bahasa pertama (B1) berlangsung ketika anak belum pernah belajar bahasa kemudaian anak tersebut memperoleh bahasa. Pemerolehan tersebut monolingual FLA (first language acquisition) yaitu memiliki satu bahasa, bisa juga dua bahasa secara bersamaan (bilingual FLA) hingga bisa lebih dari dua bahasa (multilingual FLA). Dalam pemerolehan bahasa kedua (B2) terjadi apabila seseorang mempelajari bahasa sesudah memperoleh bahasa ibunya bisa disebut juga sebagai suatu proses seseorang meningkatkan keterampilan bahasa kedua atau bahasa asing. Sudah menjadi hal biasa, bahwa proses pemerolehan B1 dan B2 seorang anak merupakan hal biasa karena ketika lahir seorang anak sudah mempunyai serangkaian alat yang digunakan dalam memperoleh B1.

Seorang anak dapat mengucapkan sebuah kalimat yang tidak pernah ia dengar sebelumnya itu dengan menggunakan kaidahkaidah tata bahasa yang mana dilakukan tanpa sadar selanjutnya diucapkan dalam hati. Vigotsky berpendapat bahwa seseorang dapat memperoleh bahasa pertama karena adanya interaksi dengan lingkungannya, meskipun ia sudah memiliki piranti bahasa yang disebut Chomsky sebagai Language Acquisition Device (LAD) kemudian kemampuan tersebut berkembang secara maksimal setelah mendapatkan respon dari lingkungannya.

Pemerolehan bahasa pada anak itu bermacam-macam, ada yang lambat, sedang, dan cepat. Biasanya hal tersebut dipengaruhi oleh beberapa faktor, yaitu:

a. Faktor Alamiah

Piranti pemerolehan bahasa yang dimiliki pada anak sejak lahir oleh Chomsky disebut Language Acuisittion Divice (LAD) itu bersifat alamiah. (Chaer, 2009). Peranti alamiah tersebut akan berkembang setelah mendapatkan rangsangan dari lingkungan sekitarnya tetapi jika tidak dirangsang oleh lingkungangannya anak tersebut tetap dapat mampu memperoleh bahasa di sekitarnya karena sifatnya yang alamiah tersebut.

b. Faktor Perkembangan Kognitif

Perkembangan bahasa anak itu sejalan dengan perkembangan kognitif yang diperolehnya. Keduanya memiliki hubungan yang bersifat saling melengkapi. Yang mana dalam prosesnya pemerolehan bahasa dibantu oleh perkembangan kognitif dan sebaliknya kemampuan kognitif berkembang dibantu dengan perkembangan bahasa yang berada di lingkup sosail. Kognitif dalam berbahasa memiliki hubunga atau keterkaitan. Lenneberg menyatakan pada usia kematangan kognitif (2 tahun) hingga usia pubertas, otak seorang anak itu masih lentur sehingga memungkinkan 
adanya pemerolehan bahasa pertama yang mudah dan cepat oleh anak. Ia juga mengatakan bahwa sesudah pubertas proses berbahasa secara alamiah agak terhambat oleh selesainya fungsi-fungsi otak tertentu, khususnya fungsi verbal otak sebelah kiri (Zasrianita, 2020).

Slobin berpendapat bahwa perkembangan kognitif dan mental merupakan faktor penentu dalam pemerolehan bahasa, anak memperoleh bahasa pertama itu dengan mengenal banyak struktur dan fungsi bahasa, dan dengan aktif ia membuat batasan-batasan pengetahuan tentang lingkungannya, dan mengembangkan kemampuan berbahasanya dengan kemampuan yang ia miliki. Slobin berpendapat pemerolehan linguistik pada anak selesai kemungkinan pada usia 3-4 tahun, kemudian perkembangan selanjutnya menggambarkan pertumbuhan kognitif anak.

Jadi faktor koginitif dan mental merupakan faktor penentu pemerolehan bahasa, yang mana pada usia dua tahun (kematangan kognitif) sampai usia pubertas itu merupakan waktu seorang anak dapat mendapatkan bahasa dengan mudah dan cepat. Hubungan antara bahasa dan kognitif, keduanya itu memiliki hubungan yang erat dan memiliki keterkiatan untuk saling melengkapi.

\section{c. Faktor Latar Sosial}

Meliputi struktur keluarga, golongan sosail, dan lingkungan masyarakat yang bisa saja terjadi perbedaan dalam pemerolehan bahasa. Dikatakan bahwa jika semakin tinggi interaksi sosial yang dilakukan maka semakin tinggi peluang seorang anak dalam memperoleh bahasa. Sebaliknya, jika semakin rendah interaksi sosial keluarga tersebut maka semakin rendah peluang anak dalam memperoleh bahasa. Anak yang dari golongan status sosial yang rendah biasanya menunjukkan perkembangan pemerolehan bahasa yang lamban.

Selain itu, perbedaan akses ke bahasa anak menunjukkan bahwa, dibandingkan dengan anak kelas bawah, kelompok kelas menengah lebih mampu menggunakan bahasa eksplisit. Keahlian anak untuk berinteraksi dengan lingkungannya dengan cara yang mudah dimengerti penting untuk menjadi anggota golongan. Anak-anak dengan keterampilan komunikasi yang kuat lebih mungkin diterima oleh kelompok sosial daripada anak-anak dengan keterampilan komunikasi yang buruk

d. Faktor Keturunan

1) Jenis Kelamin, jenis kelamin juga memengaruhi penguasaan bahasa anakanak. Umumnya anak perempuan lebih unggul dari anak laki-laki. Meski dari sejumlah kajian ilmiah, para ahli belum sepenuhnya menjelaskan hal ini.

2) Intelegensi, intelegensi atau kecerdasan juga mempengaruhi penguasaan bahasa anak, yang berkaitan dengan kemampuan anak mencerna hal tertentu melalui pikiran. Karena setiap anak memiliki bagian-bagian otak seperti IQ setiap anak yang berbedabeda.

3) Kepribadian, Gaya/Cara Pemerolehan, Kreativitas anak dalam menanggapi sesuatu memang menentukan bahasa, dan perolehan kemampuan berbicara serta perilaku yang menjadi kepribadian seorang anak mempengaruhi perubahan bahasa dan tutur kata sampai batas tertentu.

Seorang anak tidak akan tiba-tiba atau langsung memahami atau memiliki tata bahasa pertama dari semua aturan di otak, maka dari itu bahasa pertama diperoleh melalui berbagai tahap. Ingram mengatakan bahwa pemerolehan bahasa secara tradisional dibagi menjadi empat tahap, yaitu: 1) Perkembangan Pralinguistik, yaitu sejak lahir hingga akhir tahun pertama. 2) Tuturan satu kata dari sekitar 1 hingga 1,5 tahun; 3) Kombinasi kata pertama, dari sekitar 1,5 hingga 2 tahun; 4) Banyak kata (kalimat sederhana dan kompleks) dimulai pada usia tiga tahun (Ingram, 1999).

Selanjutnya, Ingram dan Stern dalam membagi pemerolehan bahasa menjadi empat tahap. Tahap pertama adalah tahap pendahuluan, yang ditandai dengan tiga jenis perilaku, yaitu mengoceh (dabbling), peniruan, dan pemahaman awal. Kedua, pada tahap pertama (1-1 tahun 6 bulan), selama tahap ini 
anak memperoleh suara dan makna khusus yang dapat mengungkapkan gagasan seluruh kalimat, tetapi tidak ada bukti bahwa anak dapat memahami tata bahasa. Ketiga, pada tahap kedua (1 tahun, 6 bulan hingga 2 tahun), pada tahap ini, anak menyadari bahwa dengan perolehan kata-kata yang terus menerus, pertanyaan tentang kata benda itu sesuatu yang memiliki makna.

Penguasaan bahasa adalah proses yang ada di dalam otak ketika seorang anak memperoleh bahasa ibunya. Proses tersebut meliputi dua aspek yaitu performa dan kompetensi. Proses performa meliputi pemahaman dan transisi, proses pemahaman menyangkutpautkan kemampuan mengamati kalimat yang didengar, dan proses transisi menyangkutpautkan kemampuan mengucapkan kalimat. Jika anak sudah menguasai kedua kemampuan tersebut, maka kedua kemampuan tersebut akan menjadi kemampuan berbahasa. Kemampuan ini meliputi tiga bagian, yaitu kemampuan fonetik, semantik, dan sintaksis yang dapat diperoleh anak pada waktu yang bersamaan.

Zuhdi dan Budiasih (1997) dalam (Nuryani dan Dona Aji Karunia Putra, 2013) membagi tahapan pemerolehan bahasa anak menjadi beberapa tingkatan bahasa, yaitu: 1) Tahap fonologis (usia 0-2 tahun), pada tahap ini anak bermain dengan bunyi bahasa tersebut, mengoceh, sampai ia mengucapkan kata-kata sederhana. 2) Tahap Sintaksis (2-7 tahun), pada tahap ini anak menunjukkan kesadaran gramatikal dan menggunakan kalimat untuk berbicara; 3) Tahap Semantik (7-11 tahun), pada tahap ini anak dapat membedakan kata sebagai simbol dan konsep kata-kata yang terkandung di dalamnya. Menurut pandangan Chaer, pada tataran sintaksis, kalimat berdasarkan pola kalimat terbagi menjadi empat bagian, yaitu kalimat deklaratif, interogatif, imperatif, dan interaktif.

Penelitian tentang pemerolehan bahasa Indonesia pada anak telah banyak dilakukan oleh para peneliti sebelumnya. Penelitian pertama yang relevan dengan penelitian ini adalah penelitian yang berjudul "Pemerolehan Bahasa Indonesia Anak Usia 2,5 Tahun (Studi
Kasus terhadap Pemerolehan Bahasa Anak Usia Dini)", penelitian tersebut dilakukan oleh Endang Rusyani, pada tahun 2008. Hasil penelitian tersebut menunjukkan bahwa seorang anak yang normal pada umur 2,3 tahun sudah dapat mengucapkan fonem-fonem dan kata yang terbatas sampai usia 2,5 tahun, dan kata yang diproduksi oleh seorang anak sudah mulai bertambah dan merangkai kata-kata secara sederhana, baik kalimat berita, kalimat imperatif, ataupun kalimat tanya sudah dapat diproduksi.

Selanjutnya, penelitian kedua yang relevan dengan judul yaitu penelitian yang berjudul "Pemerolehan Bahasa Indonesia Anak Usia 2,5 Tahun dalam Kajian Fonologi, Morfologi dan Sintaksis", penelitian tersebut dilakukan oleh Fera Zasrianita pada Juni 2020. Hasil penelitian tersebut menunjukkan bahwa: 1) Seorang anak yang normal sudah dapat mengucapkan fonemfonem, dan kata yang terbatas sesuai dengan lingkungannya dan benda-benda yang ada di skitarnya; 2) Kata-kata yang diproduksi sudah mulai bertambah mulai dari kata-kata benda dan kata-kata kerja; 3) Syafiq sudah mulai merangkai kata-kata sederhana, mulai dari satu, dua sampai tiga kata, dan akhirnya membentuk kalimat.

Selanjutnya, penelitian ketiga yang relevan dengan penelitian ini adalah penelitian yang berjudul "Pemerolehan Bahasa Pertama Terhadap Anak Usia 2 Sampai 4 Tahun Menurut Tataran Morfologi dan Sintaksis", penelitian tersebut dilakukan oleh Nur Endah, Dwi Apriliani Rahmayanti, dan Enjang Supriatna pada tahun 2018. Hasil penelitian tersebut menunjukkan bahwa: 1) pada anak usia 2-4 tahun adanya pemerolehan morfologi, yaitu munculnya bentuk morfem bebas; 2) pada anak usia 2-4 tahun adanya pemerolehan sintaksis, yaitu anak mampu mengucapkan beberapa kata yang dapat menjadi satu kalimat; 3) pada anak usia 2-4 tahun adanya pemerolehan morfologi dan sintaksis, yaitu anak mulai sempurna dalam bunyi vokal dan juga disertai bunyi konsonan. 
Berdasarkan tiga penelitian yang telah dijelaskan di atas, dapat disimpulkan bahwa terdapat perbedaan dan persamaan dengan penelitian yang akan dilakukan. Perbedaannya terletak pada sumber data dan bidang yang akan dikaji, penelitian ini hanya menggunakan tataran Morfologi dan Sintaksis, berbeda dengan penelitian yang sebelumnya yang menggunakan tataran Fonologi, Morfologi, dan Sintaksis. Persamaannya yaitu sama-sama menganalisis mengenai pemerolehan bahasa pada anak usia 2-4 tahun pada tataran Morfologi dan Sintaksis.

\section{METODE}

Metode yang digunakan dalam penelitian ini adalah metode kualitatif deskriptif dengan rancangan psikolinguistik morfologi dan sintaksis. Melalui metode kualitatif ini akan dijabarkan pemerolehan bahasa pada tataran morfologi dan sintaksis pada dua orang anak yang berada melalui percakapan dengan anggota keluarganya. Subjek penelitian yang pertama yaitu Sheva anak yang berumur 2 tahun 6 bulan yang melakukan percakapan dengan ayahanya yang bernama Mansah dan kakanya bernama Syakila. Subyek penelitian yang kedua yaitu Raya Syakila Cholis anak yang berumur 3 tahun 1 bulan yang melakukan percakapan dengan mamahnya yang bernama Rizkiah.

Lokasi penelitian yaitu berada di tempat lingkungan peneliti yaitu J1 H Suhaemi Parung Poncol RT 04/02 Kelurahan Duren Mekar Kecamatan Bojongsari kota Depok. Pengumpulan data dilakukan pada Kamis, 19 November 2020. Data penelitian berupa ujaran berbentuk percakapan yang direkam di rumah subjek masing-masing yang diperoleh dari kegiatan sehari-hari antara subjek dengan keluarganya. Kemudian rekaman tersebut akan ditranskip ke dalam bentuk tulisan.

\section{HASIL DAN PEMBAHASAN}

Berdasarkan penelitian yang telah dilakuakan, pemerolehan morfologi dan sintaksis dalam percakapan dengan keluarga dianalisis sesuai dengan teori yang relevan di bawah ini:

a. Pemerolehan Morfologi

1) Pada anak usia 2 tahun 6 bulan yang bernama Sheva

Kata yang diucapkan oleh Sheva yang berumur 2,6 tahun kebanyakan adalah kata-kata monomorfemik misalnya: /ana/: mana /nak/: anak /enda/: bunda /ajan/: jajan /eneng/: Neneng /acah/: Mansah /ma/: mak /pa/: bapak /ndak/: tidak /becok/: besok /akan/: makan /itut/: ikut /emen/ permen. Kata-kata yang diucapkan di atas bersifat monomorfemik atau memiliki satu morfem, dan belum nampak morfem yang membedakan arti kata tersebut. Kata-kata tersebut biasanya berdiri sendiri dan dalam morfologi kata-kata tersebut dinamakan morfem bebas yang memiliki arti morfem yang memiliki makna tanpa bantuan morfem lain. Monomorfemik juga bisa disebut kata dasar. Selain morfem bebas, dalam ucapan Sheva ada juga morfem terikat yang susah dibedakan dalam setiap ucapannya tanpa memerhatikan konteks dan situasi ketika kata itu diucapkan.

Jarang terdekat morfem terikat yang diucapkan oleh Sheva, tetapi tidak semua katakatanya tidak dapat membedakan arti, ada beberapa kata yang diucapkan Sheva yang sebenarnya sudah termasuk kategori morfem terikat misalnya: Ininya kata tersebut termasuk morfem terikat yang berupa klitika /nya/, yang kedua yaitu kata ambilin yang termasuk morfem terikat yang merupakan unsure gabungan /-in/.

Kata-kata yang diucapkan Sheva juga lebih banyak kata-kata yang hampir bisa dikatakan dalam konteks makna kalimat, dan ia sudah bisa mengatakan kata-kata lebih dari satu suku kata. Seperti: Ininya ana, nak Ayah, Nda Eneng, Ayah Acah, ma Iyus, Pa Aci, di Walung om, eva au ajan $\bullet<$ ininya mana, anak Ayah, bunda Neneng, ayah Mansah, ma Iyus, bapak Basri, di warung om, Sheva mau jajan. Dengan memperhatikan klausa dan susunan kata yang diucapkannya, menunjukkan bahwa Sheva dalam menyusun kalimat itu belum teratur tetapi maksud dan konteks atau makna 
yang dituju sesuai dengan ungkapan itu diucapkan.

Pada umur 2,6 tahun Sheva juga sudah mampu mengucapkan kata yang menggunakan sufiks ketika ia bertanya kepada Ayahnya mengenai suatu benda, Sheva mengucapkan: Ininya ana = Ininya mana, terdapat sufiks /nya/. Terdapat juga unsur gabungan (bentuk) ketika Sheva menyuruh ayahnya mengambil suatu barang, Sheva mengucapkan: Yah, ambilin itu, pengertian pada kata 'ambilin' tersebut atau 'in' tersebut hanya pengaruh dari Jakarta. Kata ambilin juga bisa diungkapkan dengan kata 'ambilkan' tetapi banyak orang juga menggunakan kata 'ambilin'. Karena sufiks /in/ dalam bahasa Jakarta sudah merupakan sufiks yang disisipkan pada setiap kata yang ingin ditekankannya. Jika kita lihat berarti terdapat pengaruh sufiks /in/ tersebut menandakan bahwa bahasa Sheva dipengaruhi oleh lingkungan sekitarnya, karena ia dan ayahnya merupakan warga asli Jakarta.

2) Pada anak usia 3 tahun 1 bulan yang bernama Raya

Pembendaharaan kata yang dimiliki Raya pada usia 3 tahun 1 bulan semakin banyak. Banyak ditemukan kata-kata monomorfemik yang diucapkan oleh Raya, seperti: /telol/: telor /akim/: eskrim /stobeli/: stroberi /ama/: sama/ /mendi/: mekdi /bogol/: Bogor /sekola/: sekolah /ulang/: uang /langgi/: lagi /kacih/: kasih /walung/: warung. Banyak juga kata-kata monomorfemik yang diucapkan dengan jelas, seperti: jauh, tempat, Papah, jajan, alfa, nonton, belum, om, bibi, bagi, rumah, mau, abang. Dan sudah nampak morfem yang dapat membedakan arti kata tersebut. Kata-kata tersebut biasanya berdiri sendiri dan pada tataran morfologi kata-kata tersebut dinamakan morfem bebas yang memiliki arti morfem yang memiliki makna tanpa bantuan morfem lain. Monomorfemik juga bisa disebut kata dasar. Selain morfem bebas, dalam ucapan Raya ada juga morfem terikat yaitu pada kata makanan terdapat morfem terikat yang berupa afiks /an/. Selain itu, terdapat juga morfem terikat yaitu kata ambilin dan bukain yang termasuk morfem terikat yang merupakan unsur gabungan /-in/.

Tuturan yang diucapkan oleh Raya itu lebih panjang atau bisa lebih dari satu atau dua suku kata, seperti: abang Alif, jajan ini, jajan akim (jajan es-krim), walung bibi (warung bibi), tempat papah, kaka padia, langgi nonton (lagi nonton), rumah nayong, di si om dan bibi, si Siha si Diba si Vina si Cika si Tara, Ama vina ama Diba ama Nayong ama Siha (sama vina sama Diba sama Nayong sama Siha).

Jika kita memperhatikan klausa dan rangkaian kata-kata yang diucapkan Raya, menunjukkan bahwa dalam menyusun kalimat dalam tuturannya Raya sudah mulai teratur dan lebih panjang, dia tidak hanya menggunakan dua kata tetapi tiga atau lebih. Raya juga mampu mengucapkan kata yang menggunakan sufiks (akhiran) ketika ia berbicara kepada Mamahnya yaitu pada kata makanan terdapat sufiks /-an/ di sana.

b. Pemerolehan Sintaksis

1) Pada anak usia 2 tahun 6 bulan yang bernama Sheva

Analisis pemerolehan bahasa yang dilakukan kepada Sheva termasuk bagaimana produksi bahasa dalam kalimat. Kalimat yang dihasilkan Sheva masih sangat sederhana, memerlukakan pemahaman yang terkadang susah dimengerti. Kalimat yang masih belum lengkap dan kadang terpotong-potong dan pengucapan fonem yang belum sempurna masih sering ditemukan. Tetapi hasil pemerolehan bahasa masih dapat dimengerti.

a) Kalimat deklaratif, kalimat deklaratif biasanya memasuki anak yang berumur 2,6 tahun, Sheva sebenarnya sudah bisa mengungkapkan kalimat sederhana yang dapat mengandung makna lengkap. Untuk mengetahu bagaimana kalimat deklaratif yang diungkapkan oleh Sheva, bentuk percakapan ini dapat memberikan gambaran-gambaran tersebut.

$\begin{array}{ll}\text { Sheva } & \text { : kak, Eva mau ajan. } \\ \text { Kaka } & \text { : Jajan di mana de? } \\ \text { Sheva } & \text { : Walung om } \\ \text { Kaka } & \text { : Eva mau jajan apa? }\end{array}$




$\begin{array}{ll}\text { Sheva } & : \text { Ajan acim } \\ \text { Kaka } & : \text { Apalagi } \\ \text { Sheva } & : \text { Mau emen, ka ambilin men } \\ \text { Kaka } & : \text { kaka boleh minta ga? } \\ \text { Sheva } & : \text { Nda. }\end{array}$

Kalimat-kalimat yang diucapkan di atas, nampang kalimatnya yang terpotong-potong dan ucapannya yang belum sempurna. Namun secara gramatikal, kalimat-kalimat di atas sudah dapat digolongkan dalam kalimat lengkap karena ditandai dengan Subjek (S) + Verb (V). secara umum, pada awal pemerolehan bahasa bentuk $\mathrm{S}+\mathrm{V}$ sudah bisa digolongkan dalam kalimat lengkap karena maknanya yang hampir sempurna. Contohnya pada kalimat: Ajan acim: jajan eskrim secara gramatikal dapat dimengerti jika melihat percakapan sebelumnya. Sehingga dapat dikategorikan jawaban lengkap.

b) Kalimat Imperatif, melihat kalimat Sheva yang sebelumnya pada bagian morfologi di atas, terlihat beberapa kalimat imperatif, yaitu: "Yah, ambilin itu." (Ayah ambilin itu 'menunjuk barang), "Mau emen, ka ambilin men" (Mau permen, ka ambilin peremen). Kalimat imperatif yang diucapkan Sheva sudah memiliki makna yang lengkap. Hanyasaja ucapan fonem masih belum sempurna, dan kalimat imperatifnya yang belum berurutan sesuai dengan kaidam kalimat imperatif. Walaupun demikian, susunan kalimat tersebut termasuk lazim khususnya dalam pemerolehan bahsa anak.

c) Kalimat Interogatif, meruapakan kalimat tanya untuk menanyakan sesuatu kepada orang lain, dan kadang-kadang muncul secara tiba-tiba. Pernah ketika dia berada di rumah dia bertanya kepada Ayahnya ketika melihat kakanya keluar dari rumah lalu ia bertanya kepada Ayahnya. "Kaka au keana yah?": "kaka mau kemana yah?" lalu ayahnya menjawab "Kaka mau main". Dari penjelasan tersebut dapat dilihat bahwa pemerolehan kalimat tanya Sheva sudah Nampak diucapkan tanpa berpikir. Hal tersebut menjelaskan bahwa kalimat semacam itu dapat diperoleh atau diproduksi dengan mudah.

2) Pada anak usia 3 tahun 1 bulan yang bernama Raya

Analisis pemerolehan bahasa yang dilakukan kepada Raya mencakup bagaimana perkembangan bahasa diproduksi termasuk kalimat. Kalimat yang dihasilkan oleh Raya telah menyerupai orang dewasa, meskipun ada beberapa kata yang kurang jelas tapi sudah lebih banyak kata-kata yang pelafalannya terlihat jelas. Bentuk kalimat yang dikeluarkan Raya tidak hanya sebatas dua atau tiga kata, tetapi telah memasuki multikata. Dalam pemerolehan sintaksis, Raya telah menguasai empat macam kalimat dengan baik, yaitu: kalimat deklaratif, kalimat imperative, kalimat interogatif, dan kalimat kompleks.

a) Kalimat deklaratif, pada anak usia tiga tahun atau yang terdapat pada Raya kalimat deklaratif yang digunakan sudah hampir sempurna. Kalimat deklaratif yang dihasilkan oleh Raya yaitu: "makan pake telol" pada kalimat tersebut Raya sedang menjawab pertanyaan Mamahnya yang bertanya sedang makan apa lalu ia menjawab makan pake telor, "Raya pengen jajan akim, mah" dalam kalimat tersebut Raya berbicara kepada Mamahnya jika ia ingin jajan es-krim, kemudian kalimat "di si om dan bibi" Raya menjelaskan ketika Mamahnya bertanya ingin beli es-krim di mana lalu ia menjawab di warung si om dan bibi, kemudian juga kalimat "abang Alif di walung bibi" pada kalimat tersebut Raya berbicara kepada Mamahnya bahwa abangnya yaitu bang Alif ada di warung bibi, dan yang terakhir kalimat Ama vina ama Diba ama Nayong ama Siha (sama vina sama Diba sama Nayong sama Siha) pada kalimat tersebut ia menyatakan jika jajan itu bersama nama-nama temannya yang ia sebutkan di atas. 
b) Kalimat Imperatif, kalimat imperatif yang diucapkan oleh Raya masih belum menggunakan unsure penghalus, dan masih bersifat langsung tanpa adanya kata seperti 'tolong'. Kalimat imperative yang diperoleh Raya yaitu: "Mah, ambilin itu" pada kalimat tersebut Raya menyuruh Mamahnya untuk mengambilkan barang (mainan) yang ada di atas, "Mah, pakein baju" maksud dari kalimat tersebut Raya ingin dipakaikan baju oleh Mamahnya. Dan "Mah, bukain" pada kalimat tersebut Raya menyuruh mamahnya untuk membukakan sebuah kaleng biskuit yang tidak bisa ia buka. Kalimat imperatif yang digunakan Raya sudah memiliki makna yang lengkap.

c) Kalimat Interogatif, meruapakan kalimat tanya untuk menanyakan sesuatu kepada orang lain, dan kadang-kadang muncul secara tiba-tiba. Pernah ketika ia sedang menonton kartun dan melihat tidak ada abangnya di sebelahnya ia bertanya "Mang abang mana?", selanjutnya ia juga bertanya kepada Mamahnya "kapan papa pulang mah?" ketika waktu sudah menunjukkan malam. Dari penjelasan tersebut dapat dilihat bahwa pemerolehan kalimat tanya tanpa berpikir. Hal tersebut menjelaskan bahwa kalimat semacam itu dapat diperoleh atau diproduksi dengan mudah.

Dapat di lihat dari hasil pembahasan di atas, bahwa pemerolehan bahasa pada anak dalam tataran Morfologi dan Sintaksis sejalan dengan beberapa penelitian sebelumnya, seperti pada anak usia 2,6 tahun pada tataran Morfologi kosa katanya bertambah meskipun bersifat monomorfemik dan pada tataran sintaksis pola kalimat yang dihasilkan masih sangat sederhana. Begitupun pada anak usia 3,1 tahun pada tataran Morfologi kata monomorfemiknya ketika diucapkan pelafalannya sudah jelas dan pada tataran Sintaksis sudah mampu mengucapkan beberapa jenis kalimat.

\section{KESIMPULAN}

Setelah menganalisis pemerolehan bahasa yang dilakukan terhadap dua orang anak, yang pertama anak yang bernama Sheva berumur 2 tahun 6 bulan dan yang kedua anak bernama Raya yang berumur 3 tahun 1 bulan pada tataran morfologi dan sintaksis seperti yang dijelaskan di atas, dapat disimpulkan bahwa: Pemerolehan bahasa pada tataran morfologi yang diperoleh anak yang bernama Sheva yang berusia 2 tahun 6 bulan, kata-kata yang diproduksinya itu sudah mulai bertambah meskipun itu hanya satu kata atau disebut monomorfemik, belum nampak morfem yang membedakan arti kata-kata tersebut, kata monomorfemik juga dapat dikategrikan sebagai morfem bebas dan morfem dasar, pada usia tersebut Sheva sudah bisa mengatakan katakata lebih dari satu suku kata, sudah mampu menyusun kalimat secara sederhana meskipun dalam menyusun kalimat itu belum teratur tetapi maksud dan konteks atau makna yang dituju sesuai dengan ungkapan yang diucapkan, dan sudah adanya proses afiksasi yang berupa sufiks. Sedangkan pemerolehan bahasa pada tatarna morfologi yang diperoleh anak yang bernama Raya yang berusia 3 tahun 1 bulan, kata-kata yang diproduksinya semakin banyak, banyak juga kata-kata monomorfemik yang diucapkan lebih jelas dibandingkan yang belum jelas, sudah nampak morfem yang dapat membedakan arti kata, terdapat morfem bebas dan morfem terikat, dalam menyusun kalimat dalam tuturannya Raya sudah mulai teratur dan lebih panjang, dia tidak hanya menggunakan dua kata tetapi tiga atau lebih kata, terdapat pula proses afiksasi yang berupa sufiks.

Pemerolehan bahasa pada tataran Sintaksis yang diperoleh anak yang bernama Sheva yang berusia 2 tahun 6 bulan, pola kalimat yang dihasilkan masih sangat sederhana, memerlukakan pemahaman yang kadang sulit dimengerti. Banyak kalimat yang masih tidak lengkap dan kadang terpotong-potong, pengucapan fonem yang belum sempurna, tetapi Sheva sudah dapat menghasilkan 
kalimat deklaratif, imperatif dan interogatif meskipun kalimat yang dihasilkan masih sangat sederhana. Sedangkan pemerolehan bahasa pada tataran Sintaksis yang diperoleh anak yang bernama Raya yang berusia 3 tahun 1 bulan anak tersebut sudah dapat menghasilkan kalimat yang menyerupai orang dewasa, lebih banyak kata-kata yang pelafalannya sudah jelas dibandingkan dengan yang belum jelas. Bentuk kalimat yang dikeluarkan Raya tidak hanya sebatas dua atau tiga kata, tetapi telah memasuki multikata. Raya juga sudah dapat menghasilkan kalimat deklaratif, imperative, dan interogatif yang sudah jelas.

\section{REFERENSI}

Chaer, A. (2009). Psikolinguistik Kajian Teoritik. Rineka Cipta.

Darjowisdjojo, S. dan. (2010). Psikolinguistik: Pengantar Pemahaman Bahasa Manusia. Yayasan Obor Indonesia.

Ingram, D. (1999). First Language Acquisition Method, Description, and Explanation. Cambridge University Press.

Nababan, S. dan. (1992). Psikolinguistik, Suatu Pengantar. Gramedia.

Nuryani dan Dona Aji Karunia Putra. (2013). PSIKOLINGUISTIK. Mazhab Ciputat.

Reatner, G. B. G. dan. (1998). Psycholinguistics. Harcourt Brace Collage.

Schutz, R. (2006). Stephen Krashnt's Theory of Secound Language Acquisition.

Sigel, I. and C. R. (2020). Cognitive Development from Childhood to Adolescence: A Construct//ivist Perspective.

Zasrianita, F. (2020). Pemerolehan Bahasa Indonesia Anak Usia 2,5 Tahun Dalam Kajian Fonologi, Morfologi, dan Sintaksis. Jurnal Hawa: IAIN Bengkulu, Volume 1 E. 